\title{
Regional management of multi-species fisheries on the basis of shared stocks and property rights: a Mediterranean case
}

\author{
LUCA MULAZZANI and GIULIO MALORGIO
}

Department of Agricultural Economics and Engineering, University of Bologna, Via Fanin 50, 40127 Bologna, Italy.

E-mail: luca.mulazzani@unibo.it

\begin{abstract}
SUMMARY: Fishery management is a complicated task that often results in overfishing, overcapacity, and low profits for the industry. The management of shared fish stocks is particularly problematic, especially if national authorities pursue different objectives. Multi-species fisheries add further complexity to the problem. It is no accident that management tools frequently used in Northern Europe, such as total allowable catches and individual quotas, are not applied in the Mediterranean Sea, where more target species are caught simultaneously. However, the European Commission intends to introduce a market-based driver for a strong, profitable fishing industry by phasing in transferable fishing concessions. This management approach is new for the Mediterranean, and it requires in-depth examination at institutional, legal, and economic levels. In this paper, after a review of the institutional setting, the economic perspective was analyzed by estimating the production function for the Italian small pelagic fishery in the Adriatic Sea. With the addition of Croatia to the European Union, the Adriatic Sea can become a Mediterranean communal exclusive fishing area. The results indicate that output measures such as total allowable catches and individual quotas should not cause serious discarding problems for this multi-species fishery.
\end{abstract}

Keywords: fishery management, shared stocks, property rights, Adriatic Sea, small pelagic, production function.

RESUMEN: GESTIÓN REGIONAL DE PESQUERÍAS MULTIESPECÍfICAS BASADA EN STOCKS COMPARTIDOS Y DERECHOS DE PROPIEDAD: UN CASO MEDITERRÁNEO. - El manejo de la pesca es una tarea difícil que con frecuencia tiene como resultado la sobreexplotación de los recursos, la sobrecapitalización de las pesquerías y la baja rentabilidad de la industria pesquera. El manejo de los stocks compartidos es particularmente problemático, especialmente cuando las autoridades públicas persiguen objetivos diferentes. Las pesquerías multiespecíficas aumentan la complejidad del problema. No es accidental que instrumentos de manejo utilizados con frecuencia en el Norte de Europa, como los Totales Admisibles de Capturas (TACs) y las Cuotas Individuales, no sean aplicadas en el mar Mediterráneo, donde se capturan varias especies objetivo simultáneamente. De otro lado, la Comisión Europea piensa introducir un incentivo de mercado para favorecer el sector pesquero y hacerlo más fuerte y rentable, a través de la introducción paulatina de concesiones de pesca transferibles. Este modo de manejo es nuevo para el Mediterráneo, y requiere un análisis detallado a nivel institucional, legal y económico. En este artículo, además de una reseña del contexto institucional, analizamos la perspectiva económica estimando la función de producción para la flota pelágica italiana del mar Adriático. Con la inclusión de Croacia en la Unión Europea, el mar Adriático podría convertirse en una zona de pesca exclusiva comunitaria del Mediterráneo. Los resultados indican que las medidas de control sobre la producción, como los TACs y las Cuotas Individuales, no ocasionarían serios problemas de descarte para este tipo de pesqueria.

Palabras claves: manejo pesquero, stocks compartidos, derechos de propiedad, mar Adriático, pequeños pelágicos, función de producción.

\section{INTRODUCTION}

The European Commission (2011) intends to reform the Common Fishery Policy (CFP) to introduce a market-based driver for a strong, profitable fishing industry by phasing in transferable fishing concessions that are based on catch or effort management systems. This instrument, if applied to the Mediterranean Sea, will require a new kind of partnership between countries that share fish stocks. In fact, with the sole excep- 
tion of bluefin tuna management, neither EU Mediterranean states nor third states have ever met to discuss quota allocations.

In the case of multi-species management, especially with transferable concessions, knowledge of fishery technology is necessary. From an economic perspective, this means estimating the production function for every species involved. This knowledge establishes possibilities and limits for the management of stocks that cannot be fished independently.

The objective of this paper is to discuss the application of transferable fishing concessions in the management of Mediterranean multi-species fisheries. The use of production functions will be explained and demonstrated using an empirical application to the Adriatic fishery of sardines (Sardina pilchardus) and anchovies (Engraulis encrasicolus).

Notice that the reform process of the CFP was not yet concluded during the preparation and review of this paper (fisheries ministers, at the meeting of the Council of 28 January 2013, fully agreed to reach a political agreement on the reform before mid-2013), so final decisions are missing. However, both Council and Parliament (see conclusions of the "Agriculture and Fisheries" Council meeting on 12 June 2012) seem to be oriented toward a voluntary introduction of transferable fishing concessions.

\section{Institutional framework of the Mediterranean Sea}

As defined by Munro et al. (2004), the term 'shared fish stocks', on the basis of geographical distribution of the resource and jurisdiction limits, can be broken down into four special cases: transboundary stocks (resources crossing two or more national jurisdictions), straddling stocks (stocks found both within a national jurisdiction and the adjacent high seas), highly migratory species (a special case of the former), and high seas fish stocks (stocks found exclusively in the high seas). In Northern Europe, the management of shared fish stocks normally implies output controls in addition to input controls. Every year, the European Union (EU) establishes total allowable catches (TACs) for more than 30 species in the waters of the North Sea and Atlantic Ocean. Following the principle of relative stability, which was mentioned for the first time in a Community legal instrument in EEC Regulation No. $170 / 83$, the quantities (quotas) allocated annually to the various member states are based on fixed percentages that were established according to the catches of a reference period (Morin 2000).

The adoption of measures for the allocation of fishing opportunities (provided by the Treaty on the Functioning of the European Union to the Council of the European Union) is strictly tied to the setting up of the maritime boundaries of the EU. Council Resolution of 3 November 1976 encouraged the member states to extend the limits of their fishing zones to $200 \mathrm{NM}$ of their North Sea and North Atlantic coasts (Crean
2000), creating a communal exclusive fishing area. The institution of sovereign right in a 200-NM exclusive economic zone (EEZ) was successively formalized by the United Nations Convention on the Law of the Sea in 1982.

In contrast, both allocation of fishing opportunities and EEZs have been less common in the Mediterranean Sea (at least until recently). Bluefin tuna (Thunnus thynnus) is currently the only Mediterranean species for which fisheries are internationally regulated through TACs, under the International Commission for the Conservation of Atlantic Tunas (ICCAT) framework. On the other hand, EEZs and restricted forms of EEZs such as fishery protection zones and ecological protection zones have been established relatively recently by most Mediterranean states (Suárez de Vivero et al. 2010, 2012). In regard to the Adriatic Sea, three countries (Albania, Bosnia-Herzegovina, and Montenegro) have declared no jurisdictional rights apart from territorial seas; in October 2003 Croatia declared an Ecological and Fishery Protection Zone (EFPZ) that extended jurisdiction beyond its territorial waters to the midpoint division line in the Adriatic to preserve fish stocks. However, in March 2008, the Croatian Parliament voted to suspend applying the EFPZ to EU vessels. On the other hand, in December 2011Italy declared an ecological protection zone covering only its western waters but not the Adriatic Sea. There are several reasons for the reluctance of several Mediterranean states, Italy in particular, to adopt exclusive fishing zones until recently, such as the difficulty of drawing boundaries, concern about losing access to high seas if third countries make the same decision, and the small presence of third countries' vessels in the potential exclusive fishing zones.

The General Fisheries Commission for the Mediterranean (GFCM), which is the regional fishery body established under the FAO constitution for the conservation and management of living marine resources, has preliminarily identified more than 35 shared fish stocks in the Mediterranean, corresponding to more than 25 species (GFCM 2006). Because of the current position of maritime boundaries, most of these stocks should be considered to be straddling stocks: in the Northern Adriatic, for example, stocks are found in three territorial seas (Italian, Croatian, and Slovenian territorial seas, up to $12 \mathrm{NM}$ ), in the Croatian EFPZ (open only to EU vessels), and in the high seas. If Italy established a fishery protection zone, there would be no high-sea stocks, and the stocks would be considered to be transboundary stocks instead of straddling stocks. Furthermore, considering the upcoming accession of Croatia into the EU, the stocks should be completely subjected to the CFP.

The United Nations Convention on the Law of the Sea calls upon states to cooperate, or at the very least to negotiate, with respect to the management and conservation of all categories of shared stocks (Munro et al. 2004). Several categories of institutions have been 
developed for the cooperative management of these resources. Bilateral agreements are usual in the case of transboundary stocks and to regulate the access of vessels in the territorial seas of third countries (e.g. the Fisheries Agreement between Norway and EU). More complex situations, such as the cases of straddling stocks and highly migratory species, can be managed inside a Regional Fisheries Organization framework.

\section{From TACs to property rights}

TACs and national quotas are rarely applied alone. Although TACs, when established on a solid scientific basis, actually guarantee the biological sustainability of the fisheries, the economic consequences can be unsatisfactory. Fishermen, in fact, would be forced to anticipate their national competitors in order to seize a greater share of the overall quota before it runs out. This 'race to fish' causes shorter fishing seasons and overcapitalization of the fleet. Thus, TACs have to be linked to other measures, including technical measures, fishing effort regulation or property rights (such as individual transferable quotas [ITQs] and territorial use rights in fisheries [TURFs]).

Advocates of property rights affirm that the use and management of natural resources inside a market system are only efficient if there are no externalities (Dubbink and van Vliet 1996). In a fisheries system without property rights, resource users can simply take what they want, leaving less of the resource for others. If the resource is scarce, a technical negative externality is then created (Arnason 2000). Property rights partially remove external effects because maximum limits to the exploitation of the resource are imposed, and when rights are transferable, they turn the technical externality into a pecuniary externality, the consequence of which can be solved through trading.

Under a system of individual non-transferable quotas, each company would carry out its annual optimization in accordance to the rights they have (Laxe 2006). Fishermen (their quotas established) would compete to land catches economically, raising quality, and finding good markets (Scott 2000). However, only under a transferable system can economic efficiency be achieved because the most efficient companies have the possibility to buy quota rights from the less efficient.

The social consequences of transferable rights have been debated to a great extent in the literature, and resistance to their introduction is found in many countries (McCay 2000). On the other hand, a technical limitation for the application of TACs and related individual quotas is recognized in the case of multi-species fisheries. If catches are composed of several target species or a composition of target species and by-catch species, individual (or total) quotas for one species can be exceeded before those of the others. When this happens, fishermen have to stop their fishing activity; alternatively, they can continue fishing the species they have a quota for, discarding the species whose quota has already been exceeded. Discarding of dead fishes is a harmful (and unethical) practice that counteracts the biologic rationale of the TACs system and leads to underestimated catches and biased management decisions. The European Commission (2001) is determined to ban all forms of discards in the future CFP.

Strong multi-specificity of the fisheries has generally been the main reason to exclude the use of output measures (such as TACs and individual catch quotas) in the Mediterranean Sea. Recently, the European Commission (2011) has communicated its position on the reform of the CFP. It clarified that, for a sustainable management of fish stocks, maximum sustainable yield (MSY) must be the main target, and emphasis was put on two tools: multi-annual multi-stock management plans and transferable fishing concessions. Although no mention is made of the concrete form of the right concessions and no distinction between output and input rights is made, additional information available on the Commission webpage explains unambiguously that "where fishing effort is used, as in the Mediterranean Sea, transferable fishing concessions would apply to effort allocations". A similar application inside the framework of the CFP can be found in the management of certain cod, plaice, and sole stocks of Northern Europe (Council Regulation No. 676/2007 and 44/2012), where the Council decides the level of maximum allowable effort (some authors prefer speaking of total allowable fishing effort, Marchal 1999) each year; maximum allowable effort, which is measured in kilowatt days per member state, can be successively allocated to individual vessels or groups of vessels by fixing the number of fishing days (or hours). In the Atlantic Community waters, the Spanish fleet fishing rights are expressed in terms of fishing days (MRAG consortium 2009, OECD 2006, Laxe 2006). In the Spanish fleet example, fishing rights are transferable.

\section{MATERIALS AND METHODS}

Most of the existing EU multi-annual managing plans based on TACs (such as the plan for fisheries exploiting stocks of plaice and sole in the North Sea [Reg. No. 676/2007] or the recovery plan for bluefin tuna [Reg. No. 302/2009]) demand that national fishing effort be commensurate with catch quotas. This requires knowledge of the relationship between effort and catches. This knowledge becomes even more important if management is based on input tools rather than output tools.

As mentioned above, the application of output management tools (TACs and individual catch quotas) to multi-species fisheries can be problematic because quotas for 1 species can be exceeded before those of the others. We considered a simple example of TACs allocated to a single homogenous fleet. The fishery production function is the relationship that transforms 
fishing effort into catches. We considered the following general production function:

$$
Y_{i}=f\left(N, C, A, T, B_{i}\right)
$$

where total catches of species $i\left(Y_{i}\right)$ are a function of the number of vessels $(N)$, a measure of capacity $(C)$ such as gross tonnage or engine power, a measure of fishing activity $(A)$, technology $(T)$, and the stock biomass $(B)$ of species $i$. This is true for all species $i$ caught by the fleet. When policy makers set a TAC in order to limit the catches of one species (on the basis of $B$ level), fishermen have to decrease some of the elements composing the fishing effort. Generally, the most flexible element, at least in the short run, is the activity (number of days at sea).

When TACs are set for several species, fishermen should adjust fishing effort in order to reach TACs of all species, but this is impossible unless technology is changed to permit different catch ratios between species to satisfy all the TACs. Otherwise, fishing activity has to stop or continue with discards. However, from an economic point of view, discards would not occur if the catches of all the species are needed to cover the variable costs of the fishing activity. In this case, after the quota of one species is taken, fishermen would not continue to operate because it would no longer be economical (Anderson 2000). More formally, marginal productivity must be higher than the cost of using one more unit of input (fishing day) to have discards. This means that TACs will not be the cause of discards if catches are composed of few economically important species, while they could be the cause of discards for species (whose quota has been exceeded) that are economically marginal (because of low catches or prices).

\section{Production function}

Fishing effort of a fleet is usually measured using some kind of index. Often, this index is obtained by combining more elements. In the CFP definition, "fishing effort" is the product of the capacity (vessel's tonnage in GT or engine power in $\mathrm{kW}$ ) and the activity (time at sea) of vessels. Furthermore, capacity and activity are themselves indices that combine traditional economic inputs such as capital and labour.

Despite the convenience of this approach, on a theoretical level, inputs can be combined only if the production function satisfies the condition of the Leontief theorem on separability (Huang and Lee 1976, Chambers 1988). In this paper, we assume that production technology takes the form of a Cobb-Douglas function. A Cobb-Douglas function that is defined in terms of aggregated inputs is, again, strongly separable. However, as opposed to the classic biological approach, the inputs are considered to be non-homogenous. Similar to the model used by Taylor and Prochaska (1985), we used a Cobb-Douglas production function including the stock biomass $(B)$ and several technical characteristics normally given in official statistics, such as the number of vessels $(N)$, a series of average measures of factors of capacity and activity (average GT, average engine power, average number of days at sea), and the technological progress (using an exponential trend) as inputs. We can represent it as follows:

$$
Y_{i t}=A N_{t}^{\delta} G_{t}^{\alpha_{1}} P_{t}^{\alpha_{2}} D_{t}^{\alpha_{3}} B_{i t}^{\beta} e^{\gamma t}
$$

where $G, P$ and $D$ are the average GT, average engine power $(\mathrm{kW})$, and average number of days at sea of the vessels, respectively. All the indices to be estimated $(\delta$, $\alpha_{1}, \alpha_{2}, \alpha_{3}$, and $\beta$ ) measure the elasticity of the output with respect to a specific input, with all the other inputs held constant; $A$ refers to technology, while $\gamma$ is the instantaneous rate of technological progress measuring the effect of time $(t)$; both parameters have to be estimated too.

Exponent parameters different from 1 (different from 0 in the case of $\gamma$ ) can have great economic and biologic importance, demonstrating that effort and density affect catchability (Wilberg et al. 2010). For example, $\delta$ could be lower than 1 if a fishery is subjected to gear competition or selection of suboptimal fishing locations because of the high number of vessels. In contrast, the exponent parameter of average GT and engine power $\left(\alpha_{1}\right.$ and $\left.\alpha_{2}\right)$ are higher than 1 if technology permits increasing returns to scale. Catches remain relatively high despite decreases in stock biomass $(\beta<1)$ if the stock is not randomly distributed and fishermen know the points where density is high; this situation is quite common for schooling species such as small pelagics. Finally $\gamma$, the instantaneous rate of technological progress, is an important element to consider, especially when management is realized by means of effort regulation (actually, $\gamma$ is just a coefficient measuring the effect of time: other variables besides technological progress could affect this measure).

\section{The panel approach}

The availability of effort and landings data broken down by Italian regions permits the use of a panel data approach. Because of the large number of data points (increasing the degrees of freedom) and the presence of variability in 2 directions (time and space), estimators that use panel data sets are generally considered to be more efficient than those using cross-sectional or time series data sets (Hsiao 1986, Verbeek 2004). Pooled ordinary least squares (OLS) was used for a panel data set of 5 regions and 10 years (1998-2007) estimating the log-linear version of (2). The tests to determine the significance of differing group means, the Breusch-Pagan test and the Hausman test, are all performed to verify the existence of different intercept parameters across regions and the suitability of using a fixed-effects or a random-effects model rather than pooled OLS (Hsiao 1986, Verbeek 2004). The inclusion in the model of single regional dummy variables is also tested: since in the log-linear version of (2) the constant refers to tech- 
nology, then different intercept parameters (positively or negatively affected by the values of dummy variables) would allow the differences existing at regional level to be proven and quantified (actually, different intercept parameters could also be due to environmental diversity or specific stock distribution).

The use of the panel approach entails that the total number of Italian vessels has to be broken down by region. This procedure prevented us from measuring the true (potential) competition effect (or scale effect) of the fleet. Furthermore, the Croatian vessels were not included in the model. For these reasons, we preferred to assume a unitary elasticity of the catches with respect to the number of vessels ( $\delta \equiv 1$ in Eq. 2 ). This linear relationship also involves that (2) can be considered as a per vessel production function.

\section{Short-run profit maximization}

After estimating the production functions of anchovies and sardines, it is possible to build a simple graphical tool for identifying the optimal short-run strategy of a vessel (Clark 1990). As mentioned above, days at sea are the only input that firms (vessels) can change to maximize profit in the short run. We used a vessel of average engine power $(300 \mathrm{~kW})$ with trawling technology as a reference firm. Stocks' biomasses were also assumed at average levels. Revenue was given by the sum of anchovy landings and sardine landings. The price of landings was considered an endogenous function of the total Adriatic landings (as attested by Mulazzani 2011, Mulazzani and Camanzi 2011, and Mulazzani et al. 2012). An inverse double-log demand function was then estimated as follows:

$$
\ln p=\alpha+\beta \ln q
$$

where $p$ is the average Adriatic price and $q$ is the total Adriatic landings.

Total costs per vessel were distinguished into fixed costs, capital costs (both independent from days at sea), and variable costs per day at sea. Labour costs were not included because of the difficulty of calculating them and because the revenue is habitually shared between the vessel owner and the crew members. Value added (including the reward of labour) was used instead of the economic profit as the objective of the maximization function. Assuming that every vessel has the same average characteristics, this maximization problem may be solved as a non-cooperative game with $N$ players finding the Cournot-Nash equilibrium. In this paper however, a graphical approach (instead of an analytical approach) was used.

\section{Data: the Adriatic small pelagic fishery}

Approximately $40000 \mathrm{t}$ of anchovies and 25000 $\mathrm{t}$ of sardines are caught every year in Central and Northern Adriatic (GSA17); more than $99 \%$ of the

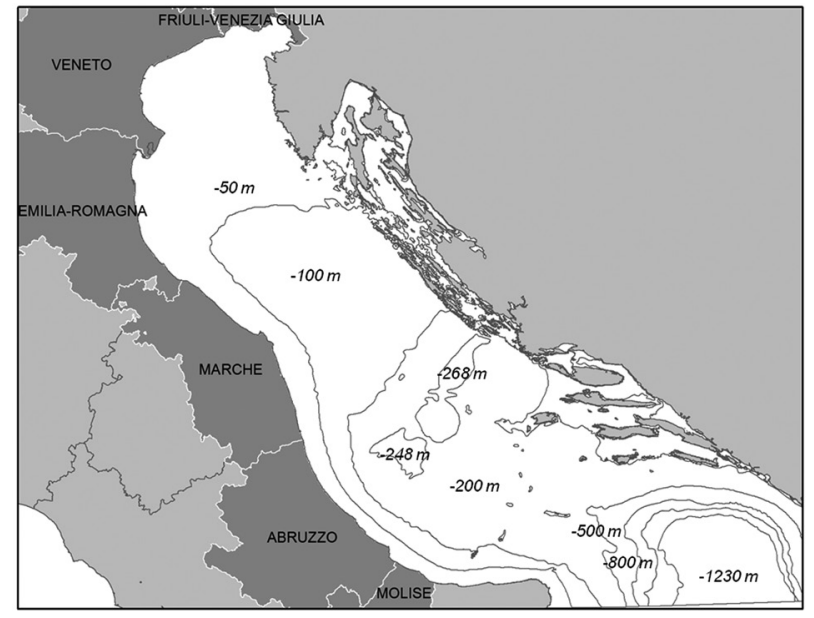

FIG. 1. - Italian regions and bathymetry of the Northern Adriatic Sea (GSA 17).

catches are attributable to the fleets of Italy and Croatia (Camanzi et al. 2012). The Italian small pelagic fleet consists of approximately 112 pair trawlers and 44 purse seiners, and fishing capacity (measured as total engine power) has had a $17 \%$ decrease in the last decade. Official Croatian statistics do not distinguish fishing effort data by gear; according to a study performed by the AdriaMed project in 2004, the Croatian small pelagic fleet was formed by 20 pelagic trawlers and 233 purse seiners. Both Italian and Croatian management tools presently include effort regulation (license scheme) and technical measures (minimum mesh sizes, minimum fish sizes, and temporary interruption of the activity).

In this paper, we used IREPA (Istituto di Ricerche Economiche per la Pesca e l'Acquacoltura) data for the effort characteristics of the Italian fleet broken down by Adriatic regions (Fig. 1). However, landings and stock biomasses of sardines and anchovies were obtained from CNR-ISMAR (Centro Nazionale delle Ricerche, Istituto di Scienze Marine) for the period 1998-2007 (latest estimations are not yet available for publication). Table 1 shows regional averages of fishing effort and landings per vessel. Vessels from Friuli Venezia Giulia (northern corner of GSA 17) and Abruzzo (in the southern part) are purse seiners, while in the other regions (central GSA 17) pelagic trawlers are used. Sea depth in front of Abruzzo coast (more than 100 meters) is higher than that in other regions.

The values in Table 1 clearly show that catches per vessel are lower in the two regions where vessels make use of purse seines. However, while the purse seiners of Friuli Venezia Giulia are small vessels (10 Gt) with low engine power $(109 \mathrm{~kW})$ and low fishing activity (104 days at sea), the purse seiners of Abruzzo are vessels with an average size $(98 \mathrm{Gt})$ and engine power $(331 \mathrm{~kW})$ that are at the same levels as those of trawlers. The fishing activity of Abruzzo's vessels (135 days) is intermediate between the small purse seiners of Friuli Venezia Giulia (104 days) and trawl- 
TABLE 1. - Average characteristics of the regional fleet and average catches per vessel. Source: IREPA, CNR-ISMAR.

\begin{tabular}{|c|c|c|c|c|c|c|}
\hline Gear - Region & $\begin{array}{l}\text { Vessels } \\
\text { (number) }\end{array}$ & $\begin{array}{c}\text { Average days } \\
\text { at sea }\end{array}$ & Average GT & $\begin{array}{l}\text { Average engine } \\
\text { power }(\mathrm{kW})\end{array}$ & $\begin{array}{c}\text { Catches of } \\
\text { anchovies per } \\
\text { vessel (t) }\end{array}$ & $\begin{array}{l}\text { Catches of } \\
\text { sardines per } \\
\text { vessel }(\mathrm{t})\end{array}$ \\
\hline \multicolumn{7}{|l|}{ Purse seine } \\
\hline Abruzzo & 26 & 135 & 98 & 331 & 37 & 4 \\
\hline Friuli Venezia Giulia & 22 & 104 & 10 & 109 & 19 & 34 \\
\hline \multicolumn{7}{|l|}{ Pelagic trawl } \\
\hline Emilia Romagna & 48 & 174 & 54 & 297 & 168 & 72 \\
\hline Marche & 26 & 160 & 121 & 434 & 252 & 50 \\
\hline Veneto & 36 & 180 & 63 & 337 & 221 & 75 \\
\hline
\end{tabular}

ers (160-180 days). This is not surprising because purse seiners (especially small vessels) are not able to operate in bad weather conditions. The average vessel-size is lower than that of other European small pelagic fleets, such as the French and Spanish fleets (according to Anderson et al. 2010, average values for the French and Spanish fleets are the following: French pelagic trawlers: Gt 237, kW 476; Spanish purse seiners: Gt 148, kW 327.)

Fixed and capital costs for a vessel of average engine power and variable costs per day at sea have been calculated using data from IREPA and STECF (Scientific, Technical and Economic Committee for Fishery; Anderson et al. 2010). Anchovy is the main target of the Italian small pelagic fishery. Anchovy prices are higher $(1.36 € / \mathrm{kg})$ than sardine prices $(1.08 € / \mathrm{kg})$ (IREPA). However, prices depend strongly on catching technology. Landings of purse seiners are usually of better quality (fishes are less damaged) and can get a higher price than the landings of trawlers. Discarding by the Adriatic small pelagic fishery has been investigated very little; Santojanni et al. (2005) concluded that moderate discarding of sardine can be found in specific geographic zones when the length of the fish is smaller than the market requirements. However, they described fishermen behaviour before the year 2000 .

Finally, data provided by CNR-ISMAR on stock biomass show, for the reference period, a stable situation for sardines, while for anchovies a peak is observed in 2005 followed by a declining period. Average biomass at sea is around $134000 \mathrm{t}$ for anchovies and $87000 \mathrm{t}$ for sardines.

\section{RESULTS}

\section{Production function}

Table 2 shows the results of pooled OLS for anchovy and sardine by using a per vessel production function (elasticity of total catches with respect to the number of vessels is assumed to be equal to 1). Average GT had to be excluded because of collinearity problems with engine power. The test result for the significance of differing group means counts against the null hypothesis that the pooled OLS model is adequate and is in favour of the fixed-effects alternative. However, tests on single regional dummy variables indicated that Abruzzo is the only region with a significantly different intercept parameter; thus, only a dummy for the Abruzzo region was added to the pooled model in order to provide an explicit quantification of the different effect of technology in this region. On the other hand, Friuli Venezia Giulia, the other region where purse seiners are used, does not have a significantly different intercept parameter. Finally, both the Breusch-Pagan test and the Hausman test counted against the randomeffects alternative.

The first impression is that the model fits the data better for the anchovy production function $\left(\mathrm{R}^{2}=0.93\right.$; all coefficients are statistically significant, except the instantaneous rate of technological progress) than for the sardine production function: in the second case, the explanatory power of the model $\left(\mathrm{R}^{2}=0.89\right)$ was almost completely attributable to the deterministic trend and dummy. It is not surprising that the Abruzzo dummy

TABLE 2. - Estimated production function coefficients and test results on residuals. The values within parentheses are standard errors. Significance level: * 10\%; ** 5\%;*** $1 \%$.

\begin{tabular}{lcc}
\hline Variable & Anchovy & Sardine \\
\hline Constant & $-13.184(2.281)^{* * *}$ & $4.690(6.725)$ \\
Engine power (P) & $1.638(0.139)^{* * *}$ & $-0.101(0.232)$ \\
Days at sea (D) & $0.814(0.295)^{* * *}$ & $0.835(0.497)^{* *}$ \\
Stock biomass (B) & $0.394(0.169)^{* * *}$ & $-0.292(0.535)$ \\
Abruzzo & $-1.446(0.118)^{* * *}$ & $-2.465(0.196)^{* * * *}$ \\
Time (t) & $0.021(0.023)$ & $-0.208(0.026)^{* * * *}$ \\
$\mathrm{R}^{2}$ & 0.93 & 0.89 \\
Adj. $\mathrm{R}^{2}$ & 0.92 & 0.87 \\
Du-Wa. Stat & $1.55(0.063)$ & $1.16(0.002)$ \\
Heterosc. ${ }^{\mathrm{a}}$ & $15.62(0.683)$ & $10.78(0.931)$ \\
Normality $^{\mathrm{b}}$ & $0.66(0.721)$ & $6.97(0.031)$ \\
\hline
\end{tabular}

a Null hypothesis that there is no heteroskedasticity was tested using the White procedure (p-value in brackets).

b Null hypothesis that residuals are normally distributed was tested using the Doornik and Hansen procedure (p-value in brackets). 

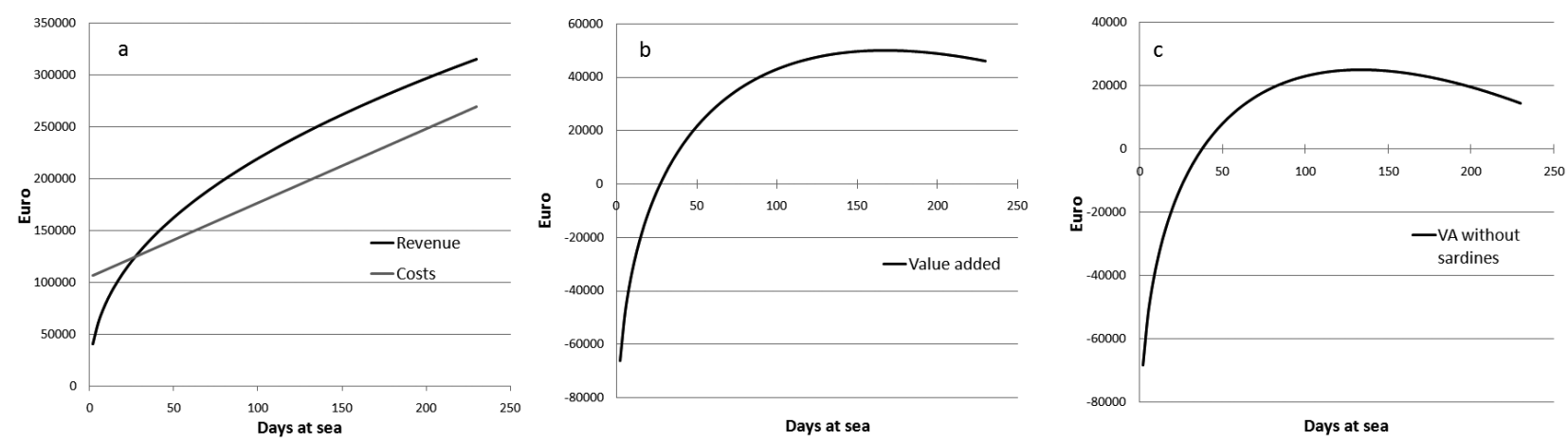

FIG. 2. - Economic results of an average vessel (with trawling technology) as a function of the number of days at sea: revenue and costs (a), value added (b), and value added if sardines are not landed (c).

showed a negative sign in both cases, because technology ( $A$ in equation (2), quantified by the intercept and dummy parameters) is different in that region. On average, a purse seiner from Abruzzo is able to catch around $75 \%$ less anchovies and $90 \%$ less sardines than a trawler of the same size.

For anchovy, the sign of all estimated coefficients was coherent with theory. Elasticity of catches with respect to engine power was greater than 1 ; catch elasticity was lower (0.81) with respect to days at sea and even lower (0.39) with respect to stock biomass. For sardine, elasticity of catches with respect to days at sea was very close to that of anchovy (0.83), while the effect of engine power and stock biomass was not statistically significant. The instantaneous rate of technological progress showed an unexpected negative sign. For anchovies, independent restriction tests were performed to verify whether the coefficients were statistically different from 1 . Statistical differences were observed for engine power and stock biomass but not for days at sea. The coefficient of days at sea was not statistically different from 1 in the sardine production function as well.

\section{Short-run value added maximization}

Results of the double-log inverse demand function using years from 1998 to 2007 indicated that the price flexibility was -0.48 for anchovies and -0.36 for sardines. These values were rather close to those obtained in a previous study ( -0.42 and -0.27 , respectively) that was performed using a longer time series and more variables (Mulazzani 2011).

Figure 2 shows revenue per vessel, total costs (excluding labour costs) per vessel, and valued added as a function of days at sea. A vessel of average engine power $(300 \mathrm{~kW})$ with trawling technology is used as a reference firm. Figure $2 \mathrm{c}$ shows the value added if sardines were not caught or if they were caught and discarded. The chart clearly shows that value added becomes positive with more than 26 fishing days. Value added then reaches its maximum (€50000) with approximately 168 days at sea, and it successively decreases because of lower catchability and lower prices.
If anchovies were the only landed species, the maximum value added would be achieved at 134 fishing days, it would be halved (€25000) and anchovy landings would be $17 \%$ lower than in the previous case.

\section{DISCUSSION}

The results of this simple model entail interesting elements of discussion. First, only the anchovy production function was observed to perfectly fit the data. This probably means that technology, including fishermen knowledge and behaviour, is strongly addressed to the catch of anchovies, while sardine catches seem to be more accidental. Second, the significance of the Abruzzo regional dummy (affecting the intercept parameter, which represents technology) showed that the pelagic fleet cannot be taken as a whole; in fact, this variable roughly assesses the efficiency differences existing between large purse seiners and pelagic trawlers. For management purposes, especially when tools affecting fishing effort are used, the fleet should be broken down into three groups: the pelagic trawlers of Veneto, Emilia Romagna, and Marche form a homogeneous group. The purse seiners of Abruzzo, which fish in the southern and deeper seas of the GSA 17, are a separate group, even though the vessel characteristics (GT, engine power) are similar to those of trawlers; efficiency of these purse seiners has proven to be lower than efficiency of trawlers, meaning that a unit of fishing effort of these vessels is not equivalent to a unit of fishing effort of a trawler. Finally, small purse seiners of the northern GSA 17 (Friuli Venezia Giulia) should form a third group, separated from the southern purse seiners of Abruzzo, because they proved to be as efficient as the pelagic trawlers.

Third, technological progress was apparently absent for the anchovy production function. This can be an advantage, at least for management purposes. Technological progress, in fact, should make management tools based on fishing effort difficult because, in order to maintain sustainability, fishing effort should be constantly reduced (Squires and Vestergaard 2009). The negative value for the sardine production function is a strange result. It would be an interesting result if it 
meant that fishermen are able to change technology to fish fewer sardines and more anchovies (thus, fishermen could easily use individual quotas). However, this result could be the effect of some biological change, such as change in the age class distribution or in the geographic concentration of the stock.

Fourth, it was noteworthy, although not surprising, that the elasticity of anchovy catches with respect to stock biomass was lower than $1(0.39)$. This implies that fishermen can easily find anchovy schools and that catches can be relatively high, although stock biomass is decreasing. This characteristic, clearly favourable for the fishery industry, should be considered because it can be responsible for unexpected stock collapse and controversies on the state of the stocks between the operators and the scientific community.

Fifth, vessel-size (using engine power as an index of fixed investments) permitted increasing returns to scale. This should provide an incentive for licence owners to use larger vessels, such as in Spain and France. However, because of the current CFP entry/ exit scheme forbidding the growth of fleet capacity, this could be achieved only with reduction of the number of vessels. The elasticity of catches with respect to days at sea was slightly lower than $1(0.81)$, meaning that there are days (or seasons) when the catchability of fish is lower because of weather conditions and distribution of the stocks.

As explained above, a firm should continue fishing as long as the revenue of a fishing day is higher than its costs. The profitability of fishing can be judged only by considering the landings of both species and price flexibility. Price drop because of abundant landings is as important as reduction in catchability for determining the optimal number of days at sea for every vessel. Without forgetting regional differences and vessel characteristics (it is quite clear that larger vessels are able to stay at sea for more days than smaller vessels), our model using a vessel of an average size (with trawling technology) can explain why the days at sea of the Adriatic fishery are fewer than the potential fishing days (approximately 230 days, excluding weekends and one imposed seasonal interruption).

The short-run value added maximization model also shows that sardines cannot be considered unimportant for the firm, even though catches and prices for sardines are lower than those of anchovies. In fact, without sardine landings, the number of profitable fishing days, anchovy catches and the value added would all be reduced. Theoretically, if firms had to discard all sardine catches (e.g. if sardine $\mathrm{TAC}=0$ ), per-vessel discard would be approximately $80 \%$ of the potential landings without limitations (no TACs).

\section{Reflections on management tools}

Our results also provide useful indications for the potential application of new management tools based on transferable fishing concessions. TACs and ITQs, in particular, could be applied knowing that discards should be of little impact. For example, TACs on anchovies should not cause any discard problems because the sardine fishery alone is not profitable and vessels would stop their activity once the anchovy quota is achieved. In the case of sardines, TACs allowing $80 \%$ (or more) of potential catches should not cause discards. However, if TACs are lower than $80 \%$ of potential catches, firms have an economic incentive to continue fishing anchovies and discard sardines.

In the long run, it is to be expected that, as the literature and prior applications suggest (Spagnolo 2006), a system based on ITQs will lead to biologic sustainability and economic efficiency, but it also entails negative social effects. More efficient firms would accumulate property rights (and capital), while working relationships on the boat would change in favour of the owner, who might sell the firm's quota, regardless of the crew's interests (McCay 2000). In the end, there will be fewer vessels and they will be larger in size. These consequences would be partly limited if restrictions of transferability were imposed between regions and gears.

On the other hand, transferability of fishing effort could be considered with respect to both activity (days at sea) and capacity ( $\mathrm{kW}$ of engine power) or a combined index of these two measures ( $\mathrm{kW}$ days). The concept of transferable fishing days seems an appropriate tool for short-run management needs, for example, when recruitment of one species fails and catches have to be quickly reduced. Apparently, this tool would cause fewer negative social consequences, because the number and size of vessels could remain the same in the long run. However, efficient firms will buy (or hire) fishing rights from less efficient firms as long as the profit of the last fishing day is equal for every firm, and some firms may decide deliberately to sell all their fishing days and leave the industry.

In the case of fishing effort concessions, biologists have to find a compromise in order to establish a reasonable optimal biomass for both species that is sustainable with a determined level of fishing effort. In fact, MSY cannot be simultaneously maintained for all species. Depending on this decision on the maximum level of fishing effort, the economic performance of the fleet may be higher or lower than that of a management system using TACs.

\section{CONCLUSIONS}

In this paper, we estimated the production functions for the fisheries of anchovies and sardines and built a graphical tool to establish the number of days at sea that permits the maximization of the value added. The results provide concrete elements of reflection to prepare new management tools for the Adriatic small pelagic fishery.

Long-term conclusions cannot be complete without a biological model that reproduces the growth of the 
stocks (see Silvestri and Maynou 2009). However, we can expect TACs and individual catch quotas to be good management tools when multi-species fisheries target few species (as in the case of the small pelagic fishery), especially if every species has economic importance. In the case of shared stocks, the initial allocation of national catch quotas can be easier than national effort quotas if, as in the case of Croatia, data on fishing effort are missing or incomplete.

However, these considerations on small pelagic fishery can hardly be applied to demersal fishery. According to GFCM (2006), there are around ten shared demersal stocks in the Adriatic Sea, and most of them are caught together by bottom trawlers. In this case, TACs are difficult to enforce, and fishing effort concessions could be managed more easily by fishermen and authorities.

In this context, the accession of Croatia into the EU (scheduled for 1 July 2013) should improve the availability of scientific and economic data and facilitate cooperation for the management of shared Adriatic resources. A communal fishing area, similar to the North Sea, would be obtained if Italy establishes a fishing protection zone to the midpoint division line. Management decisions based on transferable concessions should be easier to implement under this Community framework than under a regional fishery body such as the GFCM (a comparison between the management frameworks existing in the Adriatic Sea and in the Bay of Biscay for the anchovy fisheries is discussed in Mulazzani et al. [2013]). However, the GFCM must be the basic institution for the management of straddling stocks shared with third countries.

\section{ACKNOWLEDGEMENTS}

The authors would like to thank CNR-ISMAR Ancona for the data provided and one anonymous referee for helpful comments on the earlier version of this paper.

\section{REFERENCES}

Anderson J., Avdic E., Bartelings H., Bengstberg R., Berkenhagen J., Brodie C., Calvo C., Davidjuka I., Goti L., Guillen J., Kuzebski E., Lees J., Longoni E., Malvarosa L., Miguez A., Motova A., Moura C., Prellezo R., Souffez A., Stroie C., Thoegersen T., Virtanen J., Zanzi A. 2010. The 2010 Annual Economic Report on the European Fishing Fleet. Publications Office of the European Union, Luxembourg, $688 \mathrm{pp}$.

Anderson L.G. 2000. Selection of a property rights management system. In: Shotton R. (ed.), Use of property rights in fisheries management, FAO fisheries technical paper 404/1. FAO, pp. 26-38.

Arnason R. 2000. Property rights as a means of economic organization. In: Shotton R. (ed.), Use of property rights in fisheries management, FAO fisheries technical paper 404/1. FAO, pp. 14-25.

Camanzi L., Mulazzani L., Malorgio G. 2012. Competitiveness of Italian small pelagics in international trade. New Medit 11: 41-51.

Chambers R.G. 1988. Applied production analysis: a dual approach. Cambridge University Press, Cambridge, $334 \mathrm{pp}$.

Clark C.W. 1990. Mathematical bioeconomics: the optimal management of renewable resources. Willey Interscience Publica- tion, New York, 400 pp.

Council of the European Communities. 1983. Council Regulation (EEC) No. 170/83 establishing a community system for the conservation and management of fishery resources.

Council of the European Union. 2007. Council Regulation (EC) No. 676/2007 establishing a multiannual plan for fisheries exploiting stocks of plaice and sole in the North Sea.

Council of the European Union. 2009. Council Regulation (EC) No. 302/2009 concerning a multiannual recovery plan for bluefin tuna in the eastern Atlantic and Mediterranean.

Council of the European Union. 2012. Council Regulation (EU) No. 44/2012 fixing for 2012 the fishing opportunities available in $E U$ waters and, to EU vessels, in certain non-EU waters for certain fish stocks and groups of fish stocks which are subject to international negotiations or agreements.

Crean K. 2000. The influence of boundaries on the management of fisheries resources in the European Union: case studies from the UK. Geoforum 31: 315-328.

Dubbink W., van Vliet M. 1996. Market regulation versus co-management? Two perspectives on regulating fisheries compared. Mar. Pol. 20: 499-516.

European Commission. 2011. Proposal for a regulation if the European Parliament and the Council on the Common fishery Policy. $\operatorname{COM}(2011) 425$.

GFCM. Report of the ninth session of the Scientific Advisory Committee of the GFCM. Rome, 24-27 October 2006. Available from: ftp://ftp.fao.org/docrep/fao/009/a0889b/a0889b00.pdf

Hsiao C. 1986. Analysis of panel data. Cambridge Univ. Press, New York, $384 \mathrm{pp}$.

Huang D.S., Lee C.V. 1976. Toward a general model of fishery production. South. Econ. J. 43: 846-854.

IREPA. Database available at: http://www.irepa.org/index. php?option=com_content \&view $=$ article $\&$ id $=15 \&$ Itemid $=27 \&$ lang=it

Laxe F.G. 2006. Transferability of fishing rights: The Spanish case. Mar. Pol. 30: 379-388.

Marchal P. 1999. Which tool of management to limit discards? Paper presented at the 21st annual conference of the European Association of Fisheries Economists. Dublin, 6-10 April 1999.

McCay B.J. 2000. Resistance to changes in property rights or, why not ITQs? In: Shotton R. (ed.), Use of property rights in fisheries management, FAO fisheries technical paper 404/1. FAO, pp. 39-44.

Morin M. 2000. The fisheries resources in the European Union. The distribution of TACs: principle of relative stability and quotahopping. Mar. Pol. 34: 265-273.

MRAG, IFM, CEFAS, AZTI Tecnalia, PolEM. 2009. An analysis of existing Rights Based Management (RBM) instruments in Member States and on setting up best practices in the EU. Final Report 2009. MRAG Ltd., London, 117 pp.

Mulazzani L. 2011. Modellizzazione bioeconomica per la gestione dei piccoli pelagici nel Mar Adriatico. Ph.D. thesis, Univ. Bologna, $191 \mathrm{pp}$.

Mulazzani L., Camanzi L. 2011. Price-quantity relations and choice of the geographical market size in Italian fresh seafood products. New Medit 10: 35-42.

Mulazzani L., Camanzi L., Malorgio G. 2012. Price formation and geographic market integration: An empirical investigation of Adriatic small pelagic species. Fish. Res. 119-120: 99-107.

Mulazzani L., Curtin R., Andrés M., Malorgio G. 2013. Multilevel governance and management of shared stocks with integrated markets: The European anchovy case. Mar. Pol. 38: 407-416.

Munro G., Van Houtte A., Willmann R. 2004. The conservation and management of shared stocks: legal and economic aspects. FAO Fisheries Technical Paper 465. FAO, Rome, 67 pp.

OECD. 2006. Using market mechanisms to manage fisheries: smoothing the path. OECD, Paris, $325 \mathrm{pp}$.

Santojanni A., Cingolani N., Arneri E., Kirkwood G., Belardinelli A. Giannetti G., Coleella S., Donato F., Barry C. 2005. Stock assessment of sardine (Sardina pilchardus, Walb.) in the Adriatic Sea, with an estimate of discards. Sci. Mar. 69: 603-617.

Suárez de Vivero J.L., Martínez Alba I., Martín Jiménez J., Jiménez Sánchez C. 2010. Jurisdictional waters in the Mediterranean and Black seas (Study). IP/B/ PECH/IC/2009-087. December 2009. PE 431.602. Fisheries. http://www.europarl.europa.eu/ committees/en/studiesdownload.html?languageDocument=EN $\&$ file $=32914$ 
Suárez de Vivero J.L., Florido del Corral D., Martínez Alba I., Martín Jiménez J., Orozco Frutos G. 2012. Fisheries Cooperation in The Mediterranean and the Black Sea (note). Directorate General for Internal Policies. Policy Department B: Structural and Cohesion Policies. IP/B/PECH/IC/2012-069 November 2012. PE 495.833. Fisheries. http://www.europarl.europa.eu/ committees/en/studiesdownload.html?languageDocument=EN $\&$ file $=78711$

Scott A. 2000. Introducing property rights in fishery management. In: Shotton R. (ed.), Use of property rights in fisheries management, FAO fisheries technical paper 404/1. FAO, pp. 1-13.

Silvestri S., Maynou, F. 2009. Application of a bioeconomic model for supporting the management process of the small pelagic fishery in the Veneto Region, northern Adriatic Sea, Italy. Sci. Mar. 73: 563-572.

Squires D., Vestergaard N. 2009. Technical change and the com- mons. Working paper 09-01, Cent. Environ. Econ., Univ. California. Available at http://econ.ucsd.edu/CEE/papers/ Squires_Vestergaard_Feb2009.pdf.

Taylor T.G., Prochaska F.J. 1985. Fishing power functions in aggregate bioeconomic models. Mar. Res. Econ. 2: 87-107.

United Nations. 1982. United Nations convention on the law of the sea. UN Doc. A/Conf.62/122.

Verbeek M. 2004. Econometria. Zanichelli Editore, Bologna, 392 pp.

Wilberg M.J., Thorson J.T., Linton B.C., Berkson J. 2010. Incorporating time-varying catchability into population dynamic stock assessment models. Rev. Fish. Sci. 18: 7-24.

Scient. ed.: V. Stelzenmüller.

Received July 4, 2012. Accepted July 17, 2013.

Published online September 5, 2013. 